\title{
PERANAN PENDIDIKAN DALAM MEMPERSIAPKAN SUMBER DAYA MANUSIA DI ERA INFORMASI DAN PENGETAHUAN
}

\author{
IMAS CINTAMULYA \\ warli66@gmail.com \\ Universitas PGRI Ronggolawe Tuban \\ Jl. Manunggal 61, Tuban, Jawa Timur
}

\begin{abstract}
Abstrak. Pendidikan memiliki peran penting di era informasi dan pengetahuan, dimana terjadi perubahan yang cepat dalam banyak bidang kehidupan. Pikiran, pengetahuan, dan organisasi merupakan faktor penting dalam era informasi dan pengetahuan. Lembaga pendidikan harus dapat mempersiapkan profil lulusan yang memiliki kompetensi yang relevan dengan zaman baru atau era informasi. Beberapa kompetensi yang diperlukan untuk dapat bertahan hidup di era informasi dan pengetahuan adalah: 1) kemampuan berpikir kritis dan kemauan untuk bekerja keras, (2) kreativitas, (3) kalaborasi, (4) pemahaman lintas budaya, (5) komunikasi, (6) mengoperasikan sebuah komputer, (7) kemampuan untuk belajar secara mandiri. Dalam hal ini adalah dalam pendidikan ilmu pengetahuan harus diperkuat dengan matematika sebagai cara berpikir ilmu pengetahuan, laboratorium sains dilengkapi, pendidikan kreativitas, pengembangan pendidikan digital.
\end{abstract}

Kata kunci: pendidikan, sumber daya manusia, the age informasi dan pengetahuan, pikiran pengetahuan

\begin{abstract}
Education has an important role in the information age and knowledge, which in this era of rapid change in many areas of life. Mind, knowledge, and the organization is a prominent factor in the era of information and knowledge. Educational institution should be able to prepare the profile of graduates who have the competencies relevant to the new age or information age. Some of the competencies necessary to be able to survive in the information age and knowledge are: 1) critical thinking ability and willingness to work hard, (2) creativity, (3) kalaborasi, (4) cross-cultural understanding, (5) communication, (6) operates a computer, (7) ability to learn independently. In this regard it is in science education should be reinforced with mathematics as a way of thinking of science, science laboratories equipped, the education of creativity, development of digital education.
\end{abstract}

Key words: education, human resources, the information age and knowledge, mind knowledge

\section{PENDAHULUAN}

Abad 21 merupakan suatu masa yang diwarnai oleh munculnya era informasi. Fenomena ini merupakan era baru peradaban manusia dimana terjadi perubahan yang sangat cepat dalam berbagai bidang kehidupan. Teknologi dan ilmu pengetahuan berkembang sangat pesat dengan didukung oleh proses transformasi informasi sedemikian rupa sehingga mengakibatkan perubahan pola hidup manusia. Era informasi merupakan gelombang ketiga dari peradaban dunia. Dimana era sebelumnya adalah era pertanian dan era industri.

Ada perbedaan yang menyolok diantara ketiga era tersebut, pada era pertanian yang menonjol agar tetap survive adalah otot, karena pada saat itu produktivitas ditentukan oleh otot. Dalam era industri faktor yang menonjol adalah mesin, pekerjaan "otot" mulai digantikan dengan pekerjaan mesin, karena terbukti lebih efektif dan efisien. 
Sedangkan dalam era informasi, faktor yang menonjol adalah pikiran dan pengetahuan individu dan organisasi (Baskoro, 2009).

Perubahan "dunia" telah memberikan dampak baik positif maupun negatif pada suatu bangsa yang telah "kabur" batas kewilayahannya. Abad ke-21 diprediksi merupakan era ekonomi pengetahuan, diduga akan terjadi perubahan secara cepat, terusmenerus, dan penuh ketidakpastian yang menuntut SDM berkemampuan tinggi (intelektual dan keterampilan) sebagai modal dalam berbisnis. Perekonomian baru di abad ke-21, akan banyak ditandai oleh globalisasi, pembiasaan masyarakat, perdagangan produk, efisiensi biaya, efisiensi staf, servis pelanggan, kompleksitas proses bisnis, swalayan, dan perdagangan secara elektronik (e-commerce).

Dalam era informasi dunia menjadi seolah tanpa batas yang ditandai dengan munculnya perdagangan bebas antar pelaku ekonomi global implikasinya adalah kondisi pasar menjadi semakin kompetitif, tingginya tuntutan pelanggan khususnya berkaitan dengan kualitas produk dan ketepatan logistik, pemenuhan hak paten, faktor lingkungan produk yang kian pendek dilihat dari dimensi waktu, dan inovasi produk yang harus memiliki kecenderungan meningkat.

Banyak orang percaya bahwa ada dua jenis bisnis pada abad 21: kesatuan usaha megastrategi yang sangat besar dan yang sangat kecil. Dunia internet dan dunia jaringan membuat orang lebih mudah berdagang, di manapun di dunia ini. Jarak tidak menjadi masalah karena dapat diakses dalam satuan detik saja. Kenyataan ini menyebabkan terjadinya peningkatan populasi di pedesaan dan mendorong perpindahan dari kota besar menuju pedesaan, yang merupakan kebalikan fenomena (urbanisasi) era sebelumnya. Abad 21 ditandai oleh perubahan terus-menerus secara konstan dan lebih cepat (Galbreath, 1999).

Globalisasi ekonomi dan sistem pasar dunia menempatkan semua negara sebagai bagian dari sistem tersebut. Hal ini menyiratkan sebuah pesan bahwa agar dapat eksis di tengah persaingan semua negara tanpa kecuali harus meningkatkan efisiensi proses pemanfaatan sumber daya yang jumlahnya sangat terbatas guna menghasilkan produk pada taraf paling optimal. Kesiapan pemerintah dalam menghadapi era globalisasi perlu mendapatkan dukungan dari para pelaku bisnis dan akademisi. Strategi sumber daya manusia (SDM) perlu dipersiapkan secara seksama agar mampu menghasilkan keluaran yang mampu bersaing di tingkat dunia.

Pertanyaan mendasar adalah bagaimana dunia pendidikan menyiapkan dirinya untuk menghadapi perubahan itu dan menyiapkan tenaga kerja abad 21? Sehubungan dengan era baru ini, lembaga pendidikan dituntut untuk melakukan reformasi diri dalam rangka menyiapkan Sumber Daya Manusia (SDM) abad ke-21. Lembaga pendidikan harus menyiapkan profil lulusan yang mempunyai kompetensi yang relevan dengan era baru atau era informasi tersebut. Dalam makalah ini akan dikupas tentang bagaimana perkembangan teknologi dan informasi kaitannya dengan pasar kerja dan penyiapan SDM oleh lembaga pendidikan.

\section{PEMBAHASAN}

\section{Kenyataan Ekonomi dan Pekerja Baru: Perubahan Kondisi}

Menurut banyak ahli ekonomi, kekuatan ekonomi dan produksi pada abad 21 banyak ditentukan oleh pengetahuan dan pelayanan atau dikenal dengan knowledge based economy. Dengan kata lain, jika pada abad 20 yang berkembang pesat adalah industri dan teknologi, dimana sumber daya alam sebagai bahan bakunya. Namun pada abad 21 isyu utama bergeser pada pengetahuan, teknologi informasi dan modal intelektual dipandang sebagai daya penggerak ekonomi, di mana informasi dijadikan sebagai bahan baku. Menurut banyak ahli, abad yang akan datang merupakan abad atau era ekonomi 
pengetahuan. Gambar 1 dan Tabel 1 berikut akan menunjukkan dengan jelas perubahan era ini, dengan berbagai ciri sumber daya, teknologi, ekonomi, pengetahuan, serta ciri-ciri terkait lainnya

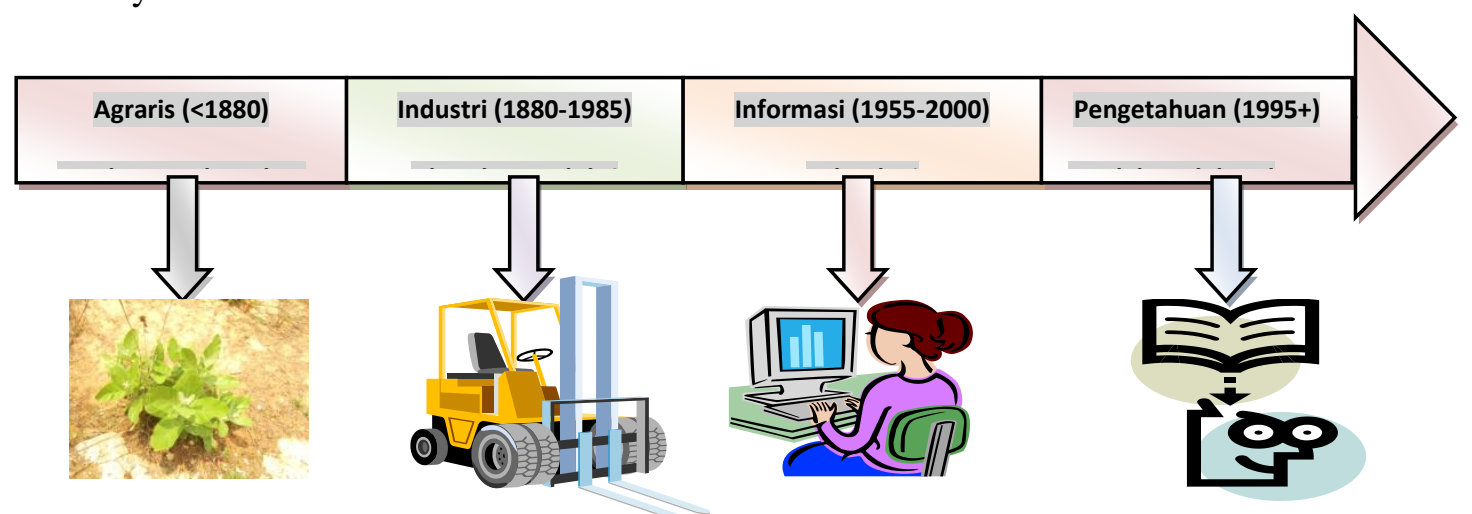

Gambar 1: Pemunculan era ekonomi pengetahuan yang menjadikan modal intelektual sebagai aset pekerja yang tidak terlihat seperti; keterampilan, pengetahuan dan pengalaman, sebagai kunci sukses di era ini (Sumber: Meta Grup).

Ilustrasi perubahan orientasi teknologi, sains, tujuan, luaran produk, sumber daya, organisasi, sumber energi, pekerjaan utama pada ketiga era yang berbeda pada Tabel 1 berikut.

Tabel 1. Karakteristik Kemajuan Ekonomi

\begin{tabular}{llll}
\hline Teknologi dominan & Bajak & INDUSTRI & $\begin{array}{c}\text { INFORMASI/ } \\
\text { PENGETAHUAN }\end{array}$ \\
Teknik sipil & Mesin & Teknik Mekanika & Komputer \\
Tains & Rekayasa biologi \\
Tujuan & Bertahan hidup & Kekayaan materi & Pertumbuhan pribadi \\
Keluaran & Makanan & Barang-barang & Informasi \\
Sumber Strategis & Tanah & Modal & Pengetahuan \\
Bentuk Organisasi & Keluarga & Korporasi & Jaringan \\
Sumber Energi & Hewan & Bahan bakar fosil & Otak/Pikiran \\
Pekerjaan Primer & Petani & Bunih/Pekerja & Wirausahawan \\
Sifat Produksi & Sendiri & Masal & Individual \\
\hline Sumb: & & &
\end{tabular}

Sumber: Worklive-Visions

Telah terjadi perubahan yang cepat dari pabrikasi ekonomi menuju ekonomi jasa. Sebagai contoh, sektor industri yang menyokong produk domestik kotor (GDP) Amerika Serikat, merosot tajam selama bertahun-tatun. Tahun 1955 memberikan sumbangan sebesar 30\%, tahun 1985 sumbangannya tercatat 21\%. Pada akhir tahun 2000, sumbangan industri terhadap GDP menurun menjadi kurang dari 17\% (Workforce 2000:xvii). Menurut hampir semua laporan ekonomi: sektor jasa akan melanjutkan kemandegan tersebut sebagai produsen pertumbuhan ekonomi dan merupakan pekerjaan yang paling besar di abad ke-21. Sulit membedakan antara ekonomi pengetahuan dan ekonomi jasa, beberapa penjelasan sering menjadi kacau. Jasa adalah tatanama standar yang digunakan untuk menggambarkan keluaran ekonomi. Jenis pekerjaan di sektor jasa ditandai oleh keluaran pengetahuan. 
Para pekerja profesional yang berasal dari; bidang ilmu pengetahuan komputer, rekayasa, manajemen, konsultan, pengajaran, pemasaran, media, dan entertain yang sebelumnya diisi oleh pekerja yang mempunyai keterampilan rendah dan upah rendah di abad ke-21 akan digantikan oleh otomatisasi teknologi dan mesin pemikir. Tipe keluaran pekerja baru berubah cepat dari produk terukur menjadi pekerja yang menciptakan, pengungkapan, dan memutar informasi menjadi pengetahuan untuk memecahkan masalah atau menghasilkan sesuatu.

Menurut Tapscott (1997) dalam Galbreath (1999) 60-70\% pekerja Amerika merupakan pekerja pengetahuan. Di mana 8 dari 10 pekerjaan baru adalah sektor informasi intensif yang berhubungan dengan ekonomi. Para pekerja di abad ke-21 tidak ditandai oleh seberapa banyak yang ia ketahui, tetapi lebih pada seberapa banyak ia dapat belajar. Perekonomian baru di abad ke-21 merupakan ekonomi pengetahuan yang ditandai oleh beberapa karakteristik kunci seperti; globalisasi, pembiasaan masyarakat, perdagangan produk, pengurangan biaya/perampingan, pengurangan staf, pelayanan pelanggan, kompleksitas proses bisnis, swalayan, dan perdagangan secara elektronik (ecommerce).

Galbreath (1999) merinci tentang perubahan-perubahan yang terjadi dalam bidang ekonomi dan dampaknya sebagai berikut:

\section{a. Globalisasi}

Bisnis tidak lagi dilakukan secara perorangan berdasarkan batas negara tetapi bisnis dilaksanakan secara serentak melalui jaringan internet, ini berarti para pekerja harus dapat berbicara sedikitnya dua bahasa untuk menemukan pekerjaan yang baru.

\section{b. Pembiasaan Masyarakat}

Di era pengetahuan atau informasi sekarang, banyak hal yang sudah berubah. Profesor Oren Harari (1997:96) menyatakan: manfaat kompetisi di dalam ekonomi berbasis pengetahuan tidak lagi tergantung pada produksi masal, pemasaran massal, pendistribusian massal, kebijakan seragam/dan skala ekonomi. Kunci sukses bisnis terietak pada masing-masing individu dengan keistimewaan unik yang diberikan pada pelanggan, di mana pembiasaan masyarakat dapat menjadi pengatur prinsip bisnis (Schonfeld Eric, 1998:117).

\section{c. Perdagangan Produk}

Pada abad ke-21 para pebisnis seperti IBM mengedapankan pelayanannya bukan bisnis produk tradisionalnya. Artinya jasa para pekerja pengetahuan sangat menentukan nilai suatu produk yang diperdagangkan.

\section{d. Pengurangan Biaya/Perampingan}

Pada abad ke-21 para pebisnis dalam rangka menekan setiap biaya yang dikeluarkan, perlu mengadakan restrukturisasi terhadap model bisnisnya dan bahkan pemberhentian sementara, sambil menata ulang.

\section{e. Pengurangan Staf/ Penghematan keterampilan}

Hasil survei CEOs 428 menunjukkan bahwa, para pekerja terampil merupakan varian yang menentukan pertumbuhan perusahaan. Dalam laporan yang sama/para eksekutif menyatakan bahwa $26 \%$ pekerja sewaan yang baru kekurangan keterampilan dasar, dan 37\% dari karyawan yang ada memerlukan peningkatan keterampilan (Grayson. 1998).

\section{f. Penekanan Pelayanan Konsumen}

Kita sudah lama mendengar bahwa konsumen adalah raja. Inovasi layanan terhadap konsumen akan menjadi ciri perdagangan di abad ke-21. Oleh karena itu yang perlu dikembangkan dan dibina adalah hubungan antara konsumen dengan produsen yang lebih dikenal dengan istilah Manajemen Hubungan Konsumen $(\mathrm{CRM}=$ Customer 
Relationship Management). Ini sangat berbeda dengan model bisnis di abad 20 yang menekankan pada inovasi produk.

\section{g. Kompleksitas Proses Bisnis}

Proses pembuatan, menjual, memasarkan. riset dan pengembangan, dan pendistribusian saling berpengaruh satu sama lain. Jika salah satu proses mengalami perencanaan ulang (setiap satu atau dua tahun) maka proses yang lain harus juga mengalaminya. Disain organisasi dan isu proses efesiensi menjadi sangat kompleks bagi perkembangan suatu bisnis.

\section{h. Swalayan}

Dari segi bisnis aplikasi swalayan merupakan bukti pemangkasan biaya yang terjadi pada banyak kasus, dari pada harus menggaji banyak orang dengan pekerjaan yang sama. Jadi para pebisnis diharapkan punya kemampuan mengaplikasikan secara subtantif jasa swalayan melalui Web secara cermat, demi masa depan usahanya.

\section{i. Perdagangan Melalui Media Elektronik (E-Commerce)}

Jika perdagan melalui media elektronik dapat menggantikan penjualan dan pelayanan konvensional, maka ini berarti bahwa para pekerja tradisional akan digantikan dengan pekerja yang memiliki keterampilan teknologi informasi atau bahkan pada tingkat kemampuan pengetahuan yang lebih tinggi. Perdagangan melalui media elektronik merupakan trend nasional dan internasional yang membutuhkan keterampilan tingkat tinggi. Di sinilah pentingnya meningkatkan kemampuan pendidikan dasar seperti matematika dan sains bagi para pekerja. Organisasi perusahan di masa yang akan datang hanya memerlukan sedikit departemen demikian pula hanya dengan ketenagakerjaan. perusahaan hanya akan memerlukan tenaga-tenaga kerja kunci saja. Di era pengetahuan atau perekonomian baru di abad ke-21; kebutuhan akan pelatihan dan pendidikan berkelanjutan bagi pekerja merupakan hal yang mutlak.

\section{Beberapa Hal yang Mendasar}

Kelangsungan perekonomian baru di abad ke-21 bergantung pada kemampuan organisasi perusahaan memperoleh data, menyaring kecerdasar yang bermanfaat, mentransformasi informasi yang bermanfaat, menyebarkannya melalui pembelajaran organisasi, serta mendifusikan kemampuan keseluruh organisasi. Edward L. Gubman dalam bukunya The Talent Solution menyebutkan kunci kebutuhan perusahaan terhadap karyawannya adalah berupa perasaan kemendesakan (urgensi), hasil, pembelajaran, dan kolaborasi.

\section{a. Perasaan Kemendesakan (Urgensi)}

Dalam hal ini diharapkan kepada para pekerja perusahaan untuk proaktif memenuhi permintaan konsumen/pelanggan yang sangat besar atau pasar yang dilayani. Ini memerlukan suatu perasaan urgensi/butuh dari semua karyawan,

b. Jasa

Perusahaan mengharapkan kepada para pekerjanya untuk terus meningkatkan hasil produk dengan kualitas yang lebih tinggi agar tetap memenuhi selera konsumen dan jaminan hasil terhadap pemegang saham.

\section{c. Pembelajaran}

Meningkatkan harapan hasil berarti karyawan harus tetap menambahkan nilai ke produk dan jasa. Artinya harus secara terus-menerus belajar keterampilan baru. Ini merupakan inti pembelajaran sepanjang hayat.

\section{d. Kolaborasi}

Perusahaan mengharapkan karyawannya agar mereka mampu berkolaborasi secara efektif dengan individu atau kelompok lain untuk menghasilkan hasil yang diinginkan demi kelangsungan bisnis: Ini merupakan konsekuensi ekonomi global. 


\section{Beberapa Dilema Pendidikan}

Apakah sistem pendidikan kita memproduksi jenis para pekerja yang dapat dengan mudah/sukses berasimilasi ke dalam era ekonomi baru dan memberikan jaminan kepada mereka akan masa depannya? Jelasnya bahwa diharapkan out put pendidikan kita menghasilkan pekerja yang memiliki keterampilan yang diperlukan untuk kesintasan dalam ekonomi pengetahuan, agar bisa tetap survive. sistem pendidikan umum sedang diserbu dari berbagai arah dengan pesaing baru, teknologi baru, dan pendekatan pendidikan yang baru. Seperti kita ketahui bahwa sebagian besar manusia menghabiskan waktu mereka di mana dia bekerja. Tanpa memperhatikan dari mana mereka mendapatkan pengetahuan, ada semacam penilaian tertutup tentang jenis keterampilan yang dibutuhkan untuk berasimilasi dan sukses dalam era perekonomian baru, serta bagaimana teknologi komputer digunakan selama proses berlangsung. Dengan memperhatikan masa depan anak didik, maka diperlukan adanya suatu penilaian yang mendekati jenis keterampilan apa yang harus diberikan agar dapat berasimilasi dan berhasil di dalam ekonomi baru dan bagaimana teknologi berbasis komputer digunakan dalam proses tersebut.

\section{Keterkaitan Teknologi Berbasis Komputer dan Keterampilan Masa Depan}

Teknologi merupakan bahasa dalam era pengetahuan. Bekerja sama dan berkolaborasi merupakan keahlian yang sangat penting dalam kinerja seseorang di mana orang tersebut dapat dijangkau secara global. Kemampuan belajar, memanipulasi, dan menggunakan berbagai variasi teknologi berbasis komputer, bekerja dalam berbagai keadaan dan lingkungan nyata akan membuat siswa semakin maju dalam mentransfer pengetahuan dan keahlian pada area dan situasi yang sulit diantisipasi. Pada intinya penggunaan teknologi dalam berbagai bidang dan situasi pembelajaran yang variatif akan membantu mempertinggi kemampuan siswa dalam hal komunikasi verbal dan tulis, penyelesaian masalah, akses informasi dan manajemen, pengambilan keputusan, serta manipulasi dan penggunaan variasi dan teknologi yang berbeda. Siswa harus belajar untuk memahami dan melakukan isu bisnis abad ke-21, dan pengetahuan tentang teknologi informasi membuat mereka melakukan start awal. Era pengetahuan dan informasi ini, kita bukan hanya memerlukan teknologi berbasis komputer sebagai sarana untuk meningkatkan pengajaran dan pencapaian tujuan pembelajaran, tetapi para siswa itu harus belajar bagaimana cara menggunakan dan menggerakkan teknologi ini supaya sintas di dalam ekonomi pengetahuan.

Hasil studi yang telah dilakukan menunjukkan bahwa teknologi elektronik dapat meningkatkan pelajaran. Di dunia teknologi yang kompleks seperti di abad ke-21, penting untuk kesintasan di tempat kerja dan di rumah. Lupakan sebentar, apakah teknologi dapat meningkatkan pelajaran berdasarkan pengujian statistik; para siswa harus belajar dan menggunakan berbagai teknologi dan merasakannya. Menurut Profesor Irving H. Buchen pendidikan klasik $3 \mathrm{R}$ (Reading, Writing, dan Arithmatic) atau Membaca, Menulis, dan Berhitung mempakan pendukung untuk pendidikan 3T (Technology, Teaming, dan Tranference) atau Teknologi, Kelompok, dan Pemindahan. Ini berarti terjadi proses transformasi pendidikan seperti Gambar 2.
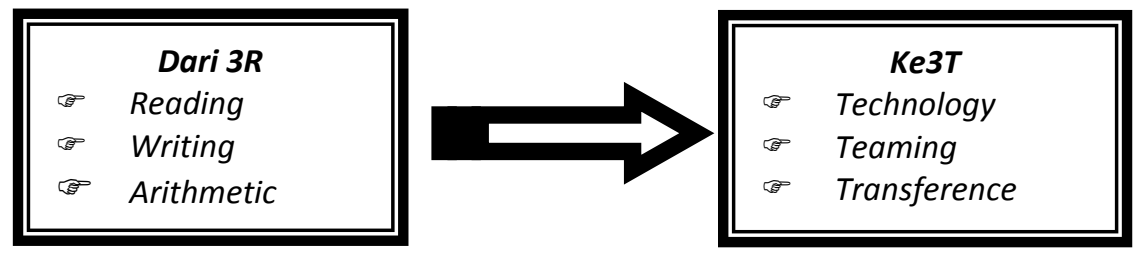

Gambar 2. Transformasi Pendidikan 
Lingkungan pembelajaran harus difokuskan pada pengajaran keterampilan dan teknik menghadapi berbagai situasi dalam ketidaktahuan, ketidakstabilan, dan dalam lingkungan yang tak dapat diduga, Sebab dalam era ekonomi secara pasti. Coba saja amati bursa saham untuk satu minggu. Dalam keadaan lancar, virtual, dinamis, dan lingkungan bisnis yang secara konstan berubah, dan inovasi merupakan sesuatu hal yang biasa. Para siswa harus diajar tentang keterampilan inovasi memecahkan permasalahan baru. Akhirnya para siswa diharapkan untuk bekerja di dalam regu sebagai kelompok pekerja dewasa. Mereka belajar dari para guru, dari kawan sekolah, dan mereka belajar dari diri mereka sendiri. Pendekatan pembelajaran banyak arah (Omni-directional) ini merupakan suatu keharusan dalam pendidikan abad ke-21. Sehubungan dengan hal tersebut dapat dilihat pada Tabel 2.

Tabel 2. Pembelajaran Pemeliharaan versus Pembelajaran movatif

\begin{tabular}{|c|c|c|}
\hline Aspek & Pembelajaran Konvensional & Pembelajaran Inovatif \\
\hline Tujuan & $\begin{array}{l}\text { Pencapaian keterampilan dan } \\
\text { tingkah laku yang diperiukan } \\
\text { untuk sukses dalam } \\
\text { pengetahuan, dan dalam } \\
\text { situasi vang dapat diprediksi }\end{array}$ & $\begin{array}{l}\text { Pencapaian keterampilan dan } \\
\text { tingkah laku yang diperiukan } \\
\text { untuk sukses dalam ketidak- } \\
\text { tahuan, dan dalam situasi unik dan } \\
\text { tidak dapat diprediksi }\end{array}$ \\
\hline Ukuran & $\begin{array}{l}\text { Solusi yang lebih baik } \\
\text { terhadap masalah lama }\end{array}$ & $\begin{array}{l}\text { Solusi yang inovatif terhadap } \\
\text { masalah baru }\end{array}$ \\
\hline Refleksi & Masa lalu & Masa yang akan datang \\
\hline Tingkah laku & Penyesuaian, seragam & Divergen, unik \\
\hline Hubungan & Kompetitif & Kooperatif \\
\hline $\begin{array}{l}\text { Aliran informasi } \\
\text { Harapan }\end{array}$ & $\begin{array}{l}\text { Atas bawah } \\
\text { (tertentu) }\end{array}$ & $\begin{array}{l}\text { Banyak arah Perluasan tidak } \\
\text { diketahui }\end{array}$ \\
\hline
\end{tabular}

Jenis keterampilan dan teknologi berbasis komputer yang harus diberikan kepada siswa untuk menghadapi abad ke-21, seperti terlihat pada Tabel 3. Sementara berbagai teknologi berbasis komputer telah digunakan di sekolah selama bertahun-tahun. Ini suatu kebaikan. Bagaimanapun, dipercaya ada 17 kunci teknologi komputer yang perlu digunakan sekarang di dalam pendidikan untuk membantu memberikan keterampilan yang diperiukan para pekerja era pengetahuan (Tabel 4).

Tabel 3. Jenis Keterampilan yang Diperlukan Pekerja Abad ke-21

\begin{tabular}{|ll|}
\hline 1. & Keterampilan Komunikasi \\
2. & Inovasi dan Kreari vitas \\
3. & Kerja Kelompok dan Pemberian Wewenang \\
4. & Manajemen Informasi \\
5. & Melek Teknologi Informasi \\
6. & Visualnetik \\
7. & Penyelesaian Masalah \\
8. & Pengambilan Keputusan \\
9. & Pengembangan Pengetahuan dan Manajemen \\
10. & Kecerdasan Bisnis \\
\hline
\end{tabular}


Tabel 4. Teknologi berbasis komputer yang diperlukan di abad 21

\begin{tabular}{|ll||}
\hline 1. & Komputer/Komputer Jaringan \\
2. & E-mail \\
3. & Video Perlengkapan Produksi \\
4. & Perangkat Lunak Basis Data (Misalnya; Microsoft Acces, Informix) \\
5. & Internet/laringan Dunia Luas \\
6. & Perangkat Lunak Manajemen Proyek (Misalnya; MS Project) \\
7. & Manajemen Pengetahuan (Misalnya; Inference, Verify, Knowlix) \\
8. & Perangkat Lunak Pendukung Keputusan (Misalnya; Cognos) \\
9. & Perangkat Lunak Presentasi (Misalnya; MS PowerPoint) \\
10. & Perangkat Lunak Grafik (Misalnya; Adobe Illustrator $)$ \\
11. & Visualisasi Data (Misalnya; Visual Insights) \\
12. & 12.Penerbitan Desktop (Misalnya; Aldus PageMaker) \\
13. & Perangkat Lunak Pengolah Kata (Misalnya; MS Word, WordPerfect) \\
14. & Perangkat Lunak Speadsheet (Misalnya; MS Excel) \\
15. & Videokonferensi (Misalnya; PictureTel) \\
16. & Groupware (Misalnya; Lotus Notes) \\
17. & Perangkat Lunak Kolaborasi Jarak Jauh (Misalnya; Net Meeting) \\
& \\
\hline
\end{tabular}

Penggunaan teknologi ini meluas ke berbagai jenis dan jejang pembelajaran, membantu meningkatkan dan mengembangkan keterampilan komunikasi verbal dan tulisan yang penting, pemecahan masalah, manajemen dan akses informasi, pengambilan keputusan, kolaborasi dan kelompok, produksi visual, manipulasi dan penggunaan berbagai teknologi yang berbeda. Sebagai contoh bagaimana teknologi pembelajaran ini menjadi pengungkapan di sekolah yang ditentukan, tabel 5 mendeskripsikan macam aktivitas yang dapat dipermudah oleh teknologi spesifik bersama hasil yang diharapkan.

\section{Sumber Daya Manusia yang Dibutuhkan Di Abad 21}

Secara umum dapat diidentifikasi ada tujuh keahlian yang harus dimiliki agar tetap survive di era informasi yaitu: (1) kemampuan berfikir kritis dan kemauan bekerja keras, (2) kreativitas, (3) kalaborasi, (4) pemahaman antar budaya, (5) komunikasi, (6) mengopersikan komputer, (7) kemampuan belajar secara mandiri. Manusia abad 21 harus mampu berfikir kritis dan kemauan kerja keras, mereka dituntut mampu mendefinisikan permasalahan kompleks yang tumpang tindih, tidak jelas domainnya; menggunakan keahlian dan perangkat yang tersedia baik manusia maupun elektronik untuk analisis dan riset; mendesain jenis tindakan dan solusi; mengatur implementasi solusi tersebut; menilai hasil; kemudian secara terus-menerus meningkatkan variasi solusi ketika kondisi berubah. Manusia pada abad 21 harus kreatif mampu menciptakan solusi baru untuk permasalahan lama, menemukan prinsip baru dan penemuan baru, menciptakan cara baru untuk mengkomunikasikan gagasan baru, menemukan cara kratif untuk mengatur proses kompleks. Manusia abad 21 harus mampu kerjasama kelompok untuk memecahkan masalah yang rumit atau untuk menciptakan perangkat kompleks, menghasilkan jasa, dan produk-produk.

Manusia abad 21 hidup di era informasi, dimana tidak ada sekat antar negara maka diperlukan kemampuan memahami budaya antar negara tanpa kehilangan akar budayanya sendiri (karakter kebangsaan). Sebagai suatu perluasan kerjasama kelompok, manusia abad 21 harus menjembatani perbedaan etnik, sosila, organisasi, politik, dan isi kultur pengetahuan dalam rangka melakukan pekerjaan mereka. Peningkatan multikultural masyarakat yang terus-menerus, pertumbuhan ekonomi global, peningkatan 
dunia teknik, dan model organisasi "jaringan" keterampilan lintas budaya tanpa kehilangan identitas asli "budayanya" akan menjadi semakin berharga.

Manusia abad 21 memerlukan kemampuan untuk berkomunikasi efektif di dalam berbagai media dengan berbagai pendengaran. Dengan memberikan sejumlah pilihan komunikasi misalnya; laporan tercetak, dokumen elektronik, majalah artikel, e-article, buku, e-book, cetakan iklan, iklan TV, iklan jaringan, telepon, telepon sel, telepon internet, surat suara, telemarketing, fax, pager, web, e-mail, selebaran, simulasi, basis data, multimedia presentasi, slides, disket, tape, vidio, CD ,DVD, radio, radio TV, TV jaringan, teleconferens. Dan yang menjadi kaharusan manusia abad 21 semua orang harus mampu menguasai komputer dasar sampai kepada suatu tingkat yang lebih tinggi untuk kelancaran 'digital dan mampu menggunakan berbagai perangkat (software) berbasis komputer untuk melaksanakn tugas hidup sehari-hari. Di abad 21 banyak pekerjaan dan permasalahan hidup menurut ketrampilan berfikir tingkat tinggi, terkait dengan hal ini menjadi hal yang mustahil hanya mengandalkan pembelajaran di sekolah, manusia abad 21 dituntut menjadi pembelajar mandiri.

Tabel 5. Keterampilan yang dipelajari dan dicari dari teknologi

\section{Aktivitas yang difasilitasi olehTeknologi Hasil yang Diharapkan}

$\begin{aligned} & \text { o Penyusunan database } \\ & \text { o Visualisasi database } \\ & o \text { Analisis informasi }\end{aligned}$
Manajemen pengetahuan

Produksi visual

Presentasi hasil kerja

Ringkasan eksekutif
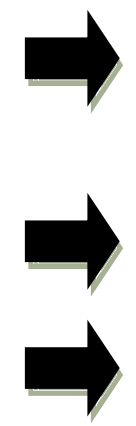

Projek kelompok

Kolaborasi virtual praktis
Belajar meneijemahkan informasi yang statis, kompleks menjadi dinamis dan mudah dipahami

Belajar membangun keterampilan komunikasi efektif

Belajar membangun keterampilan menulis efektif, mengubah sejumlah besar informasi menjadi ringkasan pengetahuan yang kritis

Mengarahkan pengembangan interpersonal dan keterampilan manajemen projek

Nilai pembelajaran di rumah sepanjang hari mengenai pekerjaan dan kolaborasi jarak jauh dengan teman pada masa-masa akhir pertemuan 


\section{Dua Puluh Penemuan Abad 20 yang Mengubah Dunia Serba Canggih Di Abad 21}

Sebagian besar aplikasi ilmu dan teknologi di awali abad 21 merupakan hasil penemuan mutakhir di abad 20. Sepanjang abad 20, telah terjadi perubahan teknologi yang sulit dibayangkan sebelumnya, terutama teknologi transistor pada tahun 1950-an yang berkembang menjadi prosesor hingga chip-chip super kecil yang terpasang pada berbagai aplikasi canggih. Belum lagi teknologi nuklir yang membawa Amerika menjadi negara Superpower hampir selama 1 abad yang sebelumnya dipegang oleh Kerajaan Inggris di abad 18 dan 19. Ada begitu banyak penemuan-penemuan ilmu dan teknologi yang telah mengubah dunia yang "kuno" pada awal abad 20 menjadi dunia serba canggih di abad 21. Teknologi abad 20 yang telah mengubah dunia ini antara lain: listrik, elektronika, robotika, TV dan radio, teknologi nuklir, mesin transportasi, komputer, internet, pesawat terbang, telepon dan seluler, rekayasa pertanian dan DNA, perminyakan, teknologi luar angkasa, AC dan kulkas, rekayasa material, teknologi kesehatan, fiber optic, fotografi, teknologi peralatan dan perlengkapan rumah tangga, moral movement (http://nuantaranews.wordpress.com.2009).

\section{Pendidikan dan Pembelajaran yang Diperlukan Menghadapi Abad 21}

Tuntutan perubahan mindset manusia abad 21, menuntut pula perubahan yang sangat besar dalam pendidikan nasional, yang kita ketahui pendidikan kita adalah warisan dari sistem pendidikan lama yang isinya menghafal fakta tanpa makna. Merubah sistem pendidikan Indonesia bukanlah pekerjaan yang mudah. Sistem pendidikan Indonesia merupakan salah satu sistem pendidikan terbesar di dunia yang meliputi sekitar 30 juta peserta didik, 200 lembaga pendidikan, dan 4 juta tenaga pendidik, tersebar dalam area yang hampir seluas benua Eropa. Namun perubahan ini merupakan sebuah keharusan jika kita tidak ingin terlindas oleh perubahan jaman global.

Terkait dalam hal ini Tilaar (2002), menyarankan guna memperkuat pendidikan sains siswa perlu diperkuat dengan penguasaan matematika, karena matematika merupakan cara berfikir sains, selain itu perlu juga sekolah dilengkapi laboratorium sains yang memadai untuk menunjang pelajaran. Hal yang lain adalah pendidikan kreativitas. Adanya Informasi yang tak terbatas memungkinkan seseorang untuk menciptakan hal baru, namun juga menyebabkan seseorang tenggelam dalam timbunan informasi yang membingungkan sehingga seseorang tidak dapat mengambil keputusan. Oleh sebab itu, salah satu sikap yang perlu dikembangkan dalam era ini adalah mengembangkan sikap kreativitas. Perlu juga dikembangkan pendidikan digital di mana setiap satuan pendidikan terkoneksi dalam jaringan digital untuk saling tukar informasi, dan lain-lain. Terkait dengan pendidikan tinggi, perguruan tinggi perlu meletakan hubungan partisipatif dengan dunia usaha dan lembaga-lembaga penelitian. Dimana selama ini hanya terkesan bersifat formal dan seremonial dan bahkan keduanya terkesan menjaga jarak dengan keangkuhannya masing-masing. Dan yang tidak kalah penting adalah pendidikan nilai sebagai pelestari `budaya` bangsa.

Terkait dengan pembelajaran, tuntutan abad 21 menurut perubahan reorientasi dalam pembelajaran yaitu dari; 1) menggeser paradigma pembelajaran dari ‘asumsi tersembunyi bahwa pengetahuan dapat dipindahakan secara utuh dari `otak/pikiran`guru ke `otak/pikiran` siswa menuju pembelajaran yang lebih `memberdayakan`seluruh aspek kemampuan siswa. 2) mengeser paradigma pembelajaran dari berpusat pada guru (teacher centred learning) menuju pembelajaran yang berpusat pada siswa (student centred learning), self directed learning (belajar mandiri), dan pemahaman diri (metakognisi) karena pembelajaran ini dirasa lebih memberdayakan siswa dalam segala aspek. 3) menggeser dari belajar "menghafal" konsep menuju belajar "menemukan" dan "membangun" (mengkonstruksi) sendiri konsep, yang terbukti mampu meningkatkan 
kemampuan siswa dalam berfikir tingkat tinggi, kritis, kreativ dan terampil memecahkan masalah, 4) menggeser dari belajar individual klasikal menuju pembelajaran kelompok kooperatif yang tidak hanya mengajari keterampilan berfikir saja namun juga mampu mengajari siswa keterampilan-keterampilan lainnya (ketrampilan sosial).

Pembelajaran yang menekan $3 \mathrm{~T}$ (teknology, Teaming, Tranference), dengan kata lain pembelajaran diwanai dan diarahkan terbentuknya penguasaan komputer, penggalang kerjasama dan penguasaan bahasa Inggris. Pembelajaran yang menekankan: membaca, menulis dan menghitung, tetap diperhatikan untuk memberi jembatan kearah penguasan komputer, bahasa dan kerjasama. Tugas yang diberikan anak adalah tugas besar (big task) yang menantang untuk melakukan kerja lapangan dan pemanfaatan teknologi komputer. Prinsip belajar (problem-solving) ditekankan, menghindari belajar hafalan (rote learning). Belajar secara kontekstual ditekankan untuk mendorong prinsip belajar bermakna. Asesmen berorientasi pada 'authentic assessment' ditekankan. Dengan kata lain, Indonesia perlu meniru Amerika untuk berpikir tentang masa depan seawal mungkin dalam mempersiapkan sumber daya masa depan dan menata kembali sistem dan praktik pendidikan. Sebuah langkah yang harus didukung oleh semua pihak.

Menurut Sidi (2001) paradigma learning jelas terlihat dalam empat visi pendidikan menuju abad 21 versi UNESCO, yakni: 1) learning to think (belajar berpikir). Ini berarti pendidikan berorientasi pada pengetahuan logis dan rasional sehingga leaner berani menyatakan pendapat dan bersikap kritis serta memiliki semangat membaca yang tinggi; 2) learning to do (belajar berbuat/hidup) hal ini terkait keterampilan siswa menyelesaikan problem keseharian atau pendidikan diarahkan pada how to solve the problem; 3) learning to live together (belajar hidup bersama) hal ini terkait pembentukan siswa yang berkesadaran bahwa hidup ini dalam sebuah dunia yang global bersama banyak manusia dari berbagai bahasa dengan latar belakang etnik, agama dan budaya. Jadi hal ini terkait akan nilai-nilai perdamaian, penghormatan HAM, pelestarian hngkungan hidup, toleransi, menjadi aspek utama yang mesti mengintemal dalam kesadaran leaner; 4) learning to be (belajar menjadi diri sendiri) hal ini penting karena masyarakat modem dilanda krisis kepribadian. Karena itu bagaimana seorang siswa di masa depannya bisa tumbuh dan berkembang sebagai pribadi yang mandiri, memiliki harga diri dan tidak sekedar memiliki materi dan jabatan politis.

Menurut Susilo (2011) ada enam unsur pembelajaran abad 21 yaitu: 1) menekankan pada mata pelajaran utama (Core subject knowledge), papun keterampilan yang dikembangkan, harus didasarkan pada pengetahuan mengenai isi materi mata pelajaran utama dan pemahaman mengenai ciri materi utama tersebut; 2) menekankan pada pengembangan keterampilan belajar; 3) memanfaatkan alat belajar abad 21 untuk mengembangkan keterampilan belajar; 4) membelajarkan siswa dalam konteks abad 21, siswa perlu belajar materi pelajaran melalui contoh-contoh, penerapan, dan pengalaman dunia nyata, baik di dalam,maupun luar sekolah; 5) membelajark

\section{PENUTUP}

Abad 21 merupakan era pengetahuan dan informasi, dimana pada era ini terjadi perubahan yang sangat cepat dalam berbagai bidang kehidupan umumnya, dan khususnya dalam bidang teknologi dan ilmu pengetahuan. Untuk itu maka dunia pendidikan perlu menyiapkan sumber daya manusia, yang memiliki keahlian agar tetap survive di era ini, yaitu: (1) kemampuan berfikir kritis dan kemauan bekerja keras, (2) kreativitas, (3) kalaborasi, (4) pemahaman antar budaya, (5) komunikasi, (6) mengopersikan komputer, (7) kemampuan belajar secara mandiri.

Terkait dengan hal ini maka dalam pendidikan sain harus diperkuat dengan matematika sebagai cara berfikir sains, dilengkapi laboratorium sains, adanya pendidikan 
kreativitas, dikembangkannnya pendidikan digital. Untuk perguruan tinggi perlu meletakan hubungan partisipatif dengan dunia usaha dan lembaga-lembaga penelitian dan yang tak kalah penting adalah pendidikan nilai sebagai pelestari 'budaya' bangsa. Di samping itu di era pengetahuan dan informasi ini, kita bukan hanya memeriukan teknologi berbasis komputer sebagai sarana untuk meningkatkan pengajaran dan pencapaian tujuan pembelajaran, tetapi para siswa itu harus belajar bagaimana cara menggunakan dan menggerakkan teknologi agar dapat berasimilasi dan berhasil di dalam ekonomi baru dan bagaimana teknologi berbasis komputer digunakan dalam proses tersebut. Oleh karena itu para siswa harus diberikan keterampilan untuk memperoleh seluruh teknologi.

\section{DAFTAR PUSTAKA}

Baskoro, A.P. 2009. Mempersiapkan Generasi di Abad 21. (online), (http://baskoro.blogspot.com/2009/06/mempersiapkan-generasi-diabad-21html/, diakses 20 Januari 2010).

Galbreath J. 1999. Preparing The 21st Century Worker: The Link Between Computer Based Technology And Future Skill Sets. Educational Technology.

Nusantaraku. 2009. 20 Penemuan Abad 20 yang Mengubah Dunia. (online), (http://nusantaranews.wordpress.com/2009/03/18/20-penemuan-abad-20yang-mengubah-dunia/, diakses 20 Januari 2010).

Sidi, I.D. 2001. Menuju Masyarakat Belajar: Menggagas Paradigma Baru Pendidikan. Jakarta: Paramadina.

Susilo, H. 2011. Bended Learning untuk Menyiapkan Siswa Hidup Di Abad 21. Universitas Negeri Malang. Seminar Nasional Pengembangan Pembelajaran Berbasis Blended Learning.

Tilaar, H.A.R. 2002. Membenahi Pendidikan Nasional. Jakarta: Rineka Cipta. 